\title{
Coronavirus Disease 2019 (COVID-19): A Cross-Sectional Survey of the Knowledge, Attitudes, Practices (KAP) and Misconceptions in the General Population of Katsina State, Nigeria
}

\author{
${ }^{* 1}$ Isah, M. B. (D), ${ }^{1}$ Abdulsalam, M. (D), 'Bello, A. (D), ${ }^{1}$ Ibrahim, M. I., ${ }^{1}$ Usman, A., ${ }^{1}$ Nasir, \\ A., ${ }^{1}$ Abdulkadir, B., ${ }^{1}$ Usman A. R. (D), ${ }^{1}$ Ibrahim, K. M., ${ }^{2}$ Sani, A., ${ }^{2}$ Aliu, M., ${ }^{3}$ Kabir, S. A., \\ ${ }^{4}$ Shuaibu, A. and ${ }^{5}$ Nass, S. S. \\ ${ }^{1}$ Faculty of Natural and Applied Sciences, Umaru Musa Yar' adua University Katsina, Nigeria \\ ${ }^{2}$ Katsina State Ministry of Health, Katsina State, Nigeria \\ ${ }^{3}$ Katsina State Primary Healthcare Agency, Katsina State, Nigeria \\ ${ }^{4}$ National Polio Emergency Operations Centre, Abuja, Nigeria \\ ${ }^{5}$ World Health Organization, North-west Zonal Office, Nigeria \\ "Corresponding Author: Email address: isah.murtala@umyu.edu.ng. Phone No: +2348034651034
}

\begin{abstract}
Over six million cases of Coronavirus Disease 2019 (COVID-19) were reported globally by the second quarter of 2020. This study assessed the COVID-19 related knowledge, attitudes, practices and misconceptions in Katsina state, Nigeria. The study is across-sectional survey of 722 respondents using an electronic questionnaire through the WhatsApp media platform. One thousand five hundred questionnaires were sent to the general public with a response rate of $48 \%$. Among the respondents, $60 \%$ were men, and $56 \%$ held bachelor's degree and above. The respondents have good knowledge of COVID-19 ( $80 \%$ correct rate on questions related to knowledge). Being more educated is associated with both higher average COVID-19 knowledge score and positive COVID-19 related practices. Overall, $>70 \%$ of the respondents have a positive attitude towards successful COVID-19 control. Male were more likely than female (Fisher's exact test $P$ value $<0.05$ ) to have recently attended a crowded place. Among the respondents, $83 \%$ held at least one misconception related to COVID-19. Respondents at all levels of education frequently chose to trust health unit and health care workers for relevant COVID-19 information. In conclusion, although there is high COVID-19 related knowledge among the respondents, misconceptions are widespread among them. These misconceptions have consequences on the short- and long-term control efforts against the disease and hence should be incorporated in targeted campaigns. Healthcare related personnel should be at the forefront of the campaign.

Kevwords: COVID-19: knowledge: attitude: practices: misconcedtions: Nigeria
\end{abstract}

INTRODUCTION

Coronavirus disease 2019 (COVID-19) caused by the SARS-CoV2 virus was detected in 213 countries and territories, with over 6 million people infected and over 371000 deaths as of $31^{\text {th }}$ May 2020. At the time, the number of people infected in Africa was 144323 with 4099 deaths. Six out of the top seven countries with most COVID-19 cases and deaths were advanced countries (Worldometer, 2020), thus, the disease is capable of overwhelming even the most advanced healthcare systems. The estimated COVID-19 viral reproduction number $\left(R_{0}\right)$, a measure of how easily the virus spreads, ranges from 1.4 to 2.5 (WHO, 2020h) or higher (Zhao et al., 2020) which indicates an easily transmittable virus. The virus is transmitted through contact and respiratory routes (WHO, 2020e). The rapid spread of the infection coupled with a short incubation period (2-14 days) (WHO, 2020b) causes an immense burden on the health care system. COVID-19 Case fatality ratios (CFR) of $7.2 \%$ in Italy, 2.3 in China and $3.0 \%$ in Nigeria have been reported (Onder et al., 2020; WHO, 2020d). The CFR highly fluctuates by country, stage of the pandemic and age group. In Africa, if COVID-19 proceeds unmitigated, an estimated 3.6-5.5 million cases would require hospitalisation among which 52000 - 107000 will require intensive care, far more than the burden African healthcare system can handle (WHO, 2020f). 
Early intervention in the spread of contagious viral infections is crucial to the control of the disease. In previous epidemics caused by other coronaviruses namely; Severe Acute Respiratory Syndrome Coronavirus (SARS-CoV) in 2003 and Middle Eastern Respiratory Syndrome (MERS), the World Health Organization (WHO) provided recommendations to break the transmission and spread of the diseases. The recommendations include early disease surveillance, case detection and isolation (Alqahtani et al., 2017; Wilder-Smith et al., 2020). Similar recommendations were used for the COVID-19 outbreak. Other recommended guidelines for the general public to prevent COVID-19 spread include voluntary home quarantine, social distancing and other measures such as frequent hand washing and covering of mouth and nose when coughing or sneezing (Ferguson et al., 2020; WHO, 2020a). Up to the third quarter of 2020 there was neither a potent vaccine nor recommended medications to treat the disease (WHO, 2020c). As such, non-medical interventions were sustained to avoid a second wave or resurgence of the disease.

Nigeria recorded its first case of COVID-19 on the $27^{\text {th }}$ February 2020 (NCDC, 2020b) and by the $31^{\text {st }}$ May 2020 the country reported 11166 confirmed cases and 315 deaths, with the majority of the COVID-19 cases from Lagos state (NCDC, 2020a). Katsina in North-west Nigeria reported 371 cases with 19 deaths in the same period. Since then, the Katsina state government imposed measures such as the closure of all schools, stay at home order and total lockdown of local government areas with an active transmission of COVID-19. While bans on inter-L.G.A. and Inter-state movements were imposed by Katsina state government and the Federal government respectively.

Both the SARS-CoV and MERS epidemics were not reported in Nigeria. However, the emergence of another viral outbreak, Ebola Viral Disease, was accompanied by unusualbehaviours and misconceptions (Iliyasu et al., 2015). Similar practices and misconceptions on COVID-19 prompted the WHO to dedicate a domain for myth buster on its website (WHO, 2020c). These include misconceptions such as that the virus is a biological weapon, the virus is not transmitted at higher temperatures and drinking alcohol or hot beverages have a protective benefit against the disease. People's perception or interpretation of disease outbreaks influences their health care seeking behaviour (Geldsetzer, 2020). As such, COVID-19 control involves understanding the factors associated with people's behaviour towards the pandemic.
For effective control, the uniqueness of various communities needs to be considered, that was why research focusing on diverse communities was required.

North-western Nigeria is the most populated geopolitical zone of the country with a population of 48.9 million, a quarter of the national projected population (National Bureau of Statistics, 2018). The Hausa-Fulani ethnic predominantly inhabits the North-West region of Nigeria and the majority of them are Muslims. Previous outbreaks of diseases such as cholera, poliomyelitis, measles and cerebrospinal meningitishave been recorded in the region (Wakabi, 2008). Notably, unhygienic water and improper hand washing practices were associated with a cholera outbreak in the North-Western state of Kano in the mid-90s (Hutin et al., 2003). More than a decade later, unhygienic hand washing practices were the main risk factors associated with a cholera outbreak in villages of the Jigawa state of the region (Gidado et al., 2018).A survey conducted between 2013-2017 found that, up to $73 \%$ of people in some rural areas of the region do not practice adequate hand washing practices using soap and water (UNICEF, 2020), and this could have a negative implication for the control of water-borne and respiratory diseases (UNICEF, 2017).

On the other hand, the obstacle for the fight against poliomyelitis in the region was a rejection of the polio vaccine, driven by misconceptions spread amongst the people (Wakabi, 2008). Thus, the frequent lack of trust and resentment towards public health intervention amongst peoples of North-Western Nigeria may likely affect the country's control efforts against COVID-19. Consequently, it became pertinent to assess the level knowledge, attitudes, practices and misconceptions towards the COVID-19 among the people of Katsina State, Nigeria. The outcome of the study will guide further research in the area with the hope to identify key variables to make informed decisions in the fight against the outbreak of COVID-19 by the relevant authorities.

\section{MATERIALS AND METHODS \\ Study design}

Due to the restrictions on movement and lockdown measures imposed on some Local Government Area (LGAs) of the state, the data for the study was collected online. The respondents in this cross-sectional survey were internet users residing in the 34 LGAs of Katsina state. The survey was conducted from $7^{\text {th }}$ May, 2020 to $18^{\text {th }}$ May, 2020. The lockdown order was 
eased in the state on $19^{\text {th }}$ May 2020 , as such Questionnaire preparation

The questionnaire was divided into sections assessing the demographic characteristics of the respondents, knowledge, attitude, practices, misconceptions and source of information related to COVID-19. The questionnaire for the knowledge, attitudes and practices towards COVID-19 was a modification of the questionnaire developed by Zhong et al. (2020), adopted with the Authors' consent obtained via email. The questionnaire consisted of 12 items on knowledge (Q1-Q12), two questions on attitude (Q13 and Q14) and three questions on practices (Q15-Q17) (Table 1). The knowledge assessed includes knowledge on clinical presentation (Q1-Q4), transmission routes (Q5-Q7) and prevention and control (Q8Q12). Three questions on COVID-19 related misconceptions were developed concerning widespread misconceptions circulating among the people since the beginning of the pandemic. Two items on the source of information were adapted from the UNICEF's Risk Communication and Community Engagement (RCCE) action plan guidance on COVID-19 preparedness and response(WHO, $2020 \mathrm{~g})$. A Hausa language translation of the questionnaire (Supplementary materials) was produced. The data collected remained anonymous. The study was approved by the research ethics committee of the State Ministry of Health, Katsina State (REF: MOH/ADM/SUB/1152/1/375).

\section{Sampling procedure}

A non-probability convenience sample of the general population was reached through volunteers recruited from our social network of contacts. The volunteers were trained, and they assisted with administering the questionnaire and receiving the responses. An invitation to participate poster was created and shared among the contacts of the data collectors and WhatsApp groups consisting mainly of people residing in Katsina state.

Data collection

The electronic questionnaires for the study were administered through the WhatsApp social media platform. An introductory message and data collection for the study was terminated. informed consent statement were sent to the respondents and the questionnaire, transcribed into strings of WhatsApp messages, was forwarded only to those who wished to participate in the survey. Out of the 1500 people contacted, 722 answered the questionnaire and 778 declined or did not respond (response rate $=48 \%$ ). The responses received were carefully collated using ODK Collect android application. An excel summary of the data was downloaded from the server (https://odk.ona.io/) on the final day of the data collection.

\section{Data analysis}

Statistical analysis was conducted using SPSS V26. Descriptive statistics such as frequencies, percentages, means and standard deviation were used to summarise qualitative data. The association between respondents' characteristics and knowledge, attitudes, practices and misconceptions towards COVID-19 were analysed using chi-square test or Fisher's exact test for categorical variables. While, the Mann-Whitney $U$ test or Kruskal Wallis test followed by Dunn's multiple comparison test were used to analyse discrete non-parametric data. The Kendall's $\tau$ coefficient was used to estimate correlation between variables. Multiple logistic regressions were used to determine the factors significantly associated with practices among the demographic variables. The best model was constructed using a backward stepwise approach. Statistical significance was considered at $P$ value $<0.05$.

\section{RESULTS}

The demographic characteristics of the sample are summarised in Table 2 . Out of the total number of the respondents, $59.6 \%$ were male, $55.1 \%$ were married and mainly residents of the Katsina senatorial zone. The respondents were predominantly educated (with 56\% having a bachelor's degree/HND or above), $<40$ years of age and were mainly students $(29.9 \%)$, employed in service $(29.9 \%)$ or engaged in physical labour, self-employment or local business $(24.4 \%)$. 
Table 1. Summary of the overall responses to the questionnaire used to assess knowledge, attitude and practices $(\mathrm{n}=722)$

Knowledge (options: true, false or I don't know)

Q1. The main clinical symptoms of COVID-19 are fever, fatigue and dry cough

$91 \%$ correct

Q2. Unlike the common cold, stuffy nose, runny nose, and sneezing are less

$61 \%$ correct common in persons infected with the COVID-19 virus

Q3. There currently is no effective cure for COVID-19, but early symptomatic and supportive treatment can help most patients recover from the infection Q4. Not all persons with COVID-19 will develop to severe cases. Only those who are elderly, have chronic illnesses, and are obese are more likely to be severe cases

Q5. Eating or contacting wild animals would result in the infection by the COVID-19 virus

Q6. Persons with COVID-19 cannot infect the virus to others when a fever is not present

Q7. The COVID-19 virus spreads via respiratory droplets of infected individuals Q8. Ordinary residents can wear general medical masks to prevent the infection by the COVID-19 virus

Q9. It is not necessary for children and young adults to take measures to prevent the infection by the COVID-19 virus

Q10. To prevent the infection by COVID-19, individuals should avoid going to crowded places such as markets and avoid taking public transportations

$90 \%$ correct

$82 \%$ correct

$42 \%$ correct

$62 \%$ correct

$87 \%$ correct

$86 \%$ correct

$71 \%$ correct

$93 \%$ correct

Q11. Isolation and treatment of people who are infected with the COVID-19 virus are effective ways to reduce the spread of the virus

$96 \%$ correct

Q12. People who have contact with someone infected with the COVID-19 virus should be immediately isolated in a proper place. In general, the observation period is 14 days

\section{Attitude}

Q13. Do you agree that COVID-19 will finally be successfully controlled? (options (agree, disagree or I don't know)

Q14. Do you have confidence that Nigeria can win the battle against the COVID-19 virus? (options: yes or no)

$95 \%$ correct

Practices (options: yes or no)

Q15. In the last two weeks, have you gone to any crowded place?

Q16. In recent days, have you worn a mask when leaving home?

Q17. In recent days, have you washed your hands with soap and water or hand sanitizer regularly?

Q18. Do you think that COVID-19 was created in the laboratory by a government or terrorist organization?

Q19. Do you think that COVID-19 was a result of technological advancement such as $5 \mathrm{G}$ ?

Q20. DO you think that COVID-19 was created to depopulate the world?

Agree (85\%); disagree $(5 \%)$;

I don't know

$(10 \%)$

Yes (71\%);

No (29\%)

Yes (40\%);

No $(60 \%)$

Yes (65\%);

No (35\%)

Yes (89\%);

No $(11 \%)$

Agree (36\%);

Disagree (28\%);

I don't know

(36\%)

Agree (19);

Disagree (42\%);

I don't know

(40\%)

Agree (33\%);

Disagree (30\%);

I don't know

(37\%) 


\section{COVID-19 knowledge}

The respondents answered nine out of the 12 questions (Q1-Q12) on COVID-19 knowledge with a correct rate of $>70 \%$ (Table 1 ). The three questions with the least correct rate were Q5 and Q6 which assessed COVID-19 related knowledge on mode of transmission and Q2 which assessed knowledge of clinical symptoms. The average correct rate (all questions) for the sample was $80 \%$ (SD $16 \%$, range $0 \%-100 \%$ ). Among the independent variables recorded, level of education significantly correlated with average knowledge scores $\left(\tau_{b}=0.16, P<0.05\right)$. COVID-19 related attitudes

We asked two questions to assess the attitude of the respondents on the final success in COVI19 control and the ability of the Nigerian government to fight the pandemic. Overall, the majority of the respondents agreed that the COVID-19 would be successfully controlled $(84 \%)$ and the Nigerian government will win the fight against the pandemic (71\%). However, across all demographic variables, a higher proportion of the respondents agreed to final success in control than to the government's ability to battle the pandemic (Table 2). The latter attitude significantly differed with the age of the respondents $(P<0.001)$. The respondents in the $25-29 \%$ age group have the least confidence in the government $(34.25 \%$ no confidence) compared to other age groups.

\section{COVID-19 related practices}

About $47 \%$ of men in the sample admitted to attending crowded places within the last two weeks, significantly more than women $(29 \%$ visited crowded places) $(P<0.0001)$ (Table 2$)$. Respondents in the age group of above 40 years were more likely to have attended a crowded place compared to other age groups $(P<0.05)$. Furthermore, employment status significantly affected the response to the question $(P<0.05)$. Civil servants abovelevel 13 (51\%), civil servants below level 12 (47\%) and respondents in physical labour/self-employment/local business $(47 \%)$ attended crowded places more than the respondents in the other employment categories. Multiple binary logistics analysis revealed that the male gender was significantly associated with visiting crowded places (vs female, $\mathrm{OR}=2.25, P<0.0001)$ (Table 3 ). 
UJMR, Volume 6 Number 1, June, 2021, pp 24 - $37 \quad$ ISSN: 2616 - 0668

Table 2. Knowledge, attitude and practices towards COVID-19 among the study respondents $(\mathrm{n}=722)^{*}$

\begin{tabular}{|c|c|c|c|c|c|c|c|}
\hline \multirow[t]{2}{*}{ Variables } & \multirow[t]{2}{*}{$\%$ total } & \multirow[t]{2}{*}{ Knowledge score ${ }^{\delta}$} & \multicolumn{2}{|l|}{ Attitude } & \multicolumn{3}{|c|}{ Practice (\% yes) } \\
\hline & & & $\begin{array}{l}\text { Final success in } \\
\text { control (\% agree) }\end{array}$ & $\begin{array}{l}\text { Confidence in } \\
\text { government (\% yes) }\end{array}$ & $\begin{array}{l}\text { Going to } \\
\text { crowded } \\
\text { places }\end{array}$ & $\begin{array}{l}\text { Wearing of } \\
\text { face mask }\end{array}$ & Washing hands \\
\hline \multicolumn{8}{|l|}{ Gender } \\
\hline Male & 59.6 & $9.50 \pm 2.00$ & 86.98 & 68.60 & 47.21‡ & 63.72 & $86.51^{\#}$ \\
\hline Female & 40.4 & $9.64 \pm 1.89$ & 81.50 & 74.32 & $28.77 \ddagger$ & 66.44 & $91.44^{\#}$ \\
\hline \multicolumn{8}{|l|}{ Age } \\
\hline $16-24$ & 37.3 & $9.55 \pm 1.90$ & 86.62 & 76.75 & $34.20^{\#}$ & 62.45 & 87.73 \\
\hline 40 and above & 17.5 & $9.41 \pm 2.09$ & 81.75 & $71.43^{\#}$ & $52.38^{\#}$ & 65.87 & 89.68 \\
\hline \multicolumn{8}{|l|}{ Marital status } \\
\hline Single & 55.1 & $9.57 \pm 2.01$ & 85.68 & 72.36 & 36.93 & 62.06 & 86.43 \\
\hline Ever Married & 44.9 & $9.54 \pm 1.89$ & 83.12 & 69.13 & 43.20 & 68.21 & 91.04 \\
\hline \multicolumn{8}{|l|}{ Education level } \\
\hline None/others & 3.0 & $7.64 \pm 2.59^{a}$ & 77.27 & 72.73 & 45.45 & $27.27 \ddagger$ & $68.18^{\#}$ \\
\hline Junior secondary school and below & 4.8 & $8.54 \pm 2.41^{\mathrm{ac}}$ & 84.71 & 85.71 & 37.14 & $48.57 \ddagger$ & $65.71^{\#}$ \\
\hline Senior secondary school & 15.2 & $9.27 \pm 2.01^{\mathrm{ab}}$ & 82.73 & 74.55 & 32.73 & $52.73 \ddagger$ & $87.27^{\#}$ \\
\hline Diploma/NCE & 20.9 & $9.49 \pm 1.99^{\mathrm{ab}}$ & 84.77 & 63.53 & 41.72 & $68.87 \ddagger$ & $88.08^{\#}$ \\
\hline \multicolumn{8}{|l|}{ Occupation } \\
\hline Physical labour/self-employed/local business & 24.5 & $9.21 \pm 2.00^{\mathrm{a}}$ & 87.36 & 68.97 & 47.42\# & 57.71 & 84.00 \\
\hline civil servant level 12 and below & 21.5 & $9.63 \pm 1.86^{\mathrm{ab}}$ & 82.47 & 62.34 & $46.45^{\#}$ & 70.97 & 91.61 \\
\hline civil servant level 13 and above/retired) & 8.4 & $9.93 \pm 1.80^{b}$ & 88.33 & 71.67 & $50.82^{\#}$ & 72.13 & 90.16 \\
\hline Student & 29.9 & $9.59 \pm 1.95^{\mathrm{ab}}$ & 84.19 & 73.49 & $29.17^{\#}$ & 63.89 & 90.28 \\
\hline Housewife & 7.3 & $9.45 \pm 2.20^{\mathrm{ab}}$ & 82.69 & 76.92 & $33.96^{\#}$ & 60.38 & 86.79 \\
\hline Unemployed & 8.6 & $9.97 \pm 1.91^{b}$ & 85.25 & 80.33 & $32.26^{\#}$ & 69.35 & 87.10 \\
\hline \multicolumn{8}{|l|}{ Place of residence } \\
\hline Daura senatorial zone & 11.5 & $9.28 \pm 1.82$ & 83.13 & 74.70 & 36.14 & 55.42 & $89.16^{\#}$ \\
\hline Funtua senatorial zone & 22.6 & $9.58 \pm 1.90$ & 80.86 & 71.60 & 47.24 & 66.26 & 79.75\# \\
\hline Katsina & 65.8 & $9.60 \pm 2.00$ & 86.37 & 70.02 & 37.82 & 65.97 & $91.39^{\#}$ \\
\hline
\end{tabular}

"Statistical significance $(P<0.05)$ is shown in bold; ${ }^{\delta}$ The difference between values with different superscripts is statistically significant $(P<0.05)$; $\ddagger P \leq 0.0001 ; \# P \leq 0.05$ 
Table 3. Multiple binary logistic regression analysis of factors significantly associated with COVID-19 related practices

\begin{tabular}{lll}
\hline Variable & OR (95\% Cl) & $P$ value \\
\hline $\begin{array}{l}\text { Going to crowded places (yes) } \\
\text { Gender (male vs female) }\end{array}$ & $2.25(1.53-3.23)$ & $<0.0001$ \\
$\begin{array}{l}\text { Washing of hands regularly (yes) } \\
\begin{array}{l}\text { Education (Bachelor's degree/HND vs Diploma/NCE or } \\
\text { lower) }\end{array}\end{array}$ & $2.11(1.28-3.56)$ & 0.0042 \\
$\begin{array}{l}\text { Education (master's and above vs Diploma/NCE or lower) } \\
\text { Place of residence (Funtua vs Katsina senatorial zones) }\end{array}$ & $4.40(1.81-13.26)$ & 0.0030 \\
\hline
\end{tabular}

The level of education significantly affected whether the respondents answered with no on Q16 (wearing a mask while leaving home) and Q17 (washing hands regularly). Only 28\% of the respondents in the none/other level of education group reported wearing a mask when leaving home. Respondents with a master's degree or higher level of education have the highest rate of face mask use and washing of hands regularly. Furthermore, the gender and place of residence of the respondents significantly affected the practice of regular hand washing $(P<0.05)$ (Table 2$)$. In a multiple logistic regression analysis, having Bachelor's degree/HND or higher level of education was significantly associated with an increased rate of hand washing (Bachelor's degree/HND vs Diploma/NCE or lower, OR $=2.11$; Master's degree and above vs Diploma/NCE or lower OR $=4.4, P$ $<0.05$ ), while living in Funtua zone is associated with the reduced rate (vs Katsina senatorial zone, $\mathrm{OR}=0.36, P=0.0001)$ (Table 3$)$.

\section{COVID-19 related misconceptions}

Out of the 722 study respondents, only 122 (17\%) answered all three questions on misconceptions with a definitive "no". Thus, $83 \%$ of the respondents held at least one or did not know the truth about a COVID-19 misconception. Among the misconceptions, 36\% of the respondents believed that COVID-19 was created in a laboratory and 33\% thought it was to depopulate the world (Table 1). Having no misconception was significantly affected only by the level of education $(P<0.0001)$ (Table 4$)$. The misconception towards COVID-19 pandemic was highest in respondents in the none/other category of the level of education (95\%) and lowest in respondents with master's and above (76\%). The average COVID-19 knowledge was $9.76 \pm 1.76$ in the respondents with no misconception and $9.52 \pm 1.99$ in the respondents who held COVID-19 related misconceptions. 
Table 4. COVID-19 related misconceptions in the sample by demographic variables and knowledge score

\begin{tabular}{|c|c|c|c|c|}
\hline \multirow[t]{2}{*}{ Variable } & \multicolumn{2}{|c|}{$\begin{array}{l}\text { Respondents with no } \\
\text { misconception }\end{array}$} & \multicolumn{2}{|c|}{$\begin{array}{l}\text { Respondents with at } \\
\text { least one } \\
\text { misconception }\end{array}$} \\
\hline & $\mathrm{n}$ & $\%$ total & $\mathrm{N}$ & $\%$ total \\
\hline \multicolumn{5}{|l|}{ Gender } \\
\hline Male & 78 & 18.14 & 352 & 81.86 \\
\hline Female & 44 & 15.07 & 248 & 84.93 \\
\hline \multicolumn{5}{|l|}{ Age group } \\
\hline $16-24$ & 39 & 14.50 & 230 & 85.50 \\
\hline $25-39$ & 63 & 19.27 & 264 & 80.73 \\
\hline 40 and above & 20 & 15.87 & 106 & 84.13 \\
\hline \multicolumn{5}{|l|}{ Marital status } \\
\hline Single & 66 & 16.58 & 332 & 83.42 \\
\hline Married & 56 & 17.28 & 268 & 82.72 \\
\hline \multicolumn{5}{|l|}{ Education level } \\
\hline None/others & 1 & $4.55 \ddagger$ & 21 & 95.45 \\
\hline Junior secondary school and below & 2 & $5.71 \ddagger$ & 33 & 94.29 \\
\hline Senior secondary school & 22 & $20.00 \ddagger$ & 88 & 80.00 \\
\hline Diploma/National certificate of Education & 2 & $13.25 \ddagger$ & 131 & 86.75 \\
\hline HND/Bachelors degree & 54 & $17.53 \ddagger$ & 254 & 82.47 \\
\hline Master's/Professional degrees and above & 23 & $23.96 \ddagger$ & 73 & 76.04 \\
\hline \multicolumn{5}{|l|}{ Occupation } \\
\hline $\begin{array}{l}\text { Physical labour/self employed/local } \\
\text { business }\end{array}$ & 24 & 13.71 & 151 & 86.29 \\
\hline civil servant level 12 and below & 31 & 20.00 & 124 & 80.00 \\
\hline civil servant level 13 and above/retired & 14 & 22.95 & 47 & 77.05 \\
\hline Student & 37 & 17.13 & 179 & 82.87 \\
\hline Housewife & 06 & 11.32 & 47 & 88.68 \\
\hline Unemployed & 10 & 16.13 & 52 & 83.87 \\
\hline \multicolumn{5}{|l|}{ Place of residence } \\
\hline Daura senatorial zone & 14 & 16.87 & 69 & 83.13 \\
\hline Funtua senatorial zone & 23 & 14.11 & 140 & 85.89 \\
\hline Katsina senatorial zone & & 17.86 & & 82.14 \\
\hline Knowledge score & \multicolumn{2}{|c|}{$9.76 \pm 1.76$} & \multicolumn{2}{|c|}{$9.52 \pm 1.99$} \\
\hline
\end{tabular}

$\ddagger P \leq 0.0001$

\section{Sources of information}

The number of channels/sources per respondents in terms of where they receive information was 3.6 , whereas the number of trusted channels/sources per respondent was 2.4 (Table 5). FM radio stations were among the main source of information on COVID-19 in the respondents with level of education of Diploma/NCE and below (Table 5). Furthermore, friends or family members were frequently selected as sources of information by the respondentswith level of education of senior secondary school or below. On the other hand, respondents with education level of bachelor's degree/HND and above frequently selected WhatsApp and other social media, internet browsing and TV stations (local, national and international) as sources of UMYU Journal of Microbiology Research information. While the respondents with the level of education of none/others trusted mainly the sources they receive information on COVID-19 from, respondents with a higher level of education trust sources different from where they mainly receive information. Notably, respondents in all levels of education frequently reported that they trust Health unit/Health care workers. Despite this, only respondents in the junior secondary school group have Health unit/Health care workers in the top four sources of COVID-19 related information. 
Table 5. Sources of COVID-19 related information by respondent's level of education.

\begin{tabular}{|c|c|c|c|c|}
\hline $\begin{array}{l}\text { Level of } \\
\text { education }\end{array}$ & $\begin{array}{l}\text { No of Source of } \\
\text { information per } \\
\text { respondent }\end{array}$ & Main source of information & $\begin{array}{l}\text { No of Source of } \\
\text { information } \\
\text { likely to trust } \\
\text { per respondent }\end{array}$ & Main source of information likely to trust \\
\hline Others/none & 2.7 & $\begin{array}{l}\text { - FM radio stations }(55 \%) \\
\text { - Family members }(50 \%) \\
\text { - Local TV stations }(27 \%) \\
\text { - Any person from the community }(23 \%)\end{array}$ & 1.8 & $\begin{array}{l}\text { - FM radio stations }(45 \%) \\
\text { - Family members/other radio stations }(23 \%) \\
\text { - Local TV stations }(18 \%) \\
\text { - Health unit/Health care Any person from the } \\
\text { community }(14 \%)\end{array}$ \\
\hline $\begin{array}{l}\text { Junior } \\
\text { secondary and } \\
\text { below }\end{array}$ & 3.1 & $\begin{array}{l}\text { - FM radio stations }(40 \%) \\
\text { - Friends }(37 \%) \\
\text { - Health unit/Health care worker }(29 \%) \\
\text { - Social media/internet browsing }(26 \%)\end{array}$ & 2.6 & $\begin{array}{l}\text { - } \text { FM radio stations }(43 \%) \\
\text { - Health unit/Health care worker }(34 \%) \\
\text { - Social media }(23 \%) \\
\text { - Other radio stations/family }(20 \%)\end{array}$ \\
\hline $\begin{array}{l}\text { Senior } \\
\text { secondary } \\
\text { school }\end{array}$ & 3.3 & $\begin{array}{l}\text { - FM radio stations }(32 \%) \\
\text { - WhatsApp/internet browsing }(30 \%) \\
\text { - Friends }(29 \%) \\
\text { - Family }(27 \%)\end{array}$ & 2.0 & $\begin{array}{l}\text { - International TV stations }(24 \%) \\
\text { - Other TV stations }(19 \%) \\
\text { - Health unit/Health care worker/FM radio } \\
\text { stations/local TV stations/internet browsing (16\%) }\end{array}$ \\
\hline Diploma/NCE & 3.4 & $\begin{array}{l}\text { - WhatsApp }(38 \%) \\
\text { - FM radio stations/social media }(32 \%) \\
\text { - Local TV stations/other TV stations }(27 \%)\end{array}$ & 2.3 & $\begin{array}{l}\text { - FM radio stations }(25 \%) \\
\text { - Local TV stations/international TV stations }(23 \%) \\
\text { - Health unit/Health care worker }(22 \%) \\
\text { - Other TV stations/WhatsApp }(21 \%)\end{array}$ \\
\hline $\begin{array}{l}\text { Bachelor's } \\
\text { degree/HND }\end{array}$ & 3.5 & $\begin{array}{l}\text { - Social media (not WhatsApp) }(41 \%) \\
\text { - Internet browsing/WhatsApp/other TV stations (36\%) } \\
\text { - International TV stations (30\%) } \\
\text { - Local TV stations }(26 \%)\end{array}$ & 2.4 & $\begin{array}{l}\text { - Other TV stations }(30 \%) \\
\text { - Health unit/Health care worker/international TV } \\
\text { stations }(28 \%) \\
\text { - Internet browsing }(27 \%) \\
\text { - WhatsApp }(17 \%)\end{array}$ \\
\hline $\begin{array}{l}\text { Master's and } \\
\text { above }\end{array}$ & 5.1 & $\begin{array}{l}\text { - International TV stations / WhatsApp (49\%) } \\
\text { - Internet browsing }(48 \%) \\
\text { - Other TV stations (47\%) } \\
\text { - Local TV stations }(39 \%)\end{array}$ & 3.1 & $\begin{array}{l}\text { - International TV stations }(46 \%) \\
\text { - Health unit/Health care }(42 \%) \\
\text { - Other TV stations }(36 \%) \\
\text { - Internet browsing }(31 \%)\end{array}$ \\
\hline Average & 3.6 & - & 2.4 & - \\
\hline
\end{tabular}




\section{DISCUSSION}

This study assessed the level of COVID-19 related knowledge, attitudes, practices as well as misconceptions in a predominantly MuslimHausa society of Katsina state in Nigeria. An overall COVID-19 related knowledge of $80 \%$ in the study sample indicated high knowledge of the clinical symptoms, mode of transmission and control measures against the disease. This finding was not surprising since the study was conducted when active COVID-19 control measures, such as the lockdown that directly affected every individual in the state, were active. Similar studies in Nigeria, and countries within Africa such as Tanzania (Dorcas et al., 2020), Ghana (Rugarabamu et al., 2020) and beyond such as China (Zhong et al., 2020) and Malaysia (Azlan et al., 2020) revealed good COVID-19 knowledge in the study subjects that consisted of people with internet access. This finding could reflect the extensive media coverage of the disease and governments' responses throughout the pandemic. However, one cause for concern on the outcome of the study is the low level of knowledge on COVID19 transmission by asymptomatic infected individuals (knowledge Q6, 62\% correct rate) in the respondents. There have been reports of COVID-19 transmission by asymptomatic (Bai et al., 2020; Yu and Yang, 2020) as well as presymtomatic (Arons et al., 2020) individuals, with a negative implication on the fight against the disease (Gandhi et al., 2020). Since the positive response rate to the question (Q6) increased with increasing level of education (Supplementary Table 1) like the average knowledge score (Table 2), enlightenment programmes on asymptomatic transmission should be included in local health promotional campaigns, targeting especially those with lower levels of education.

Okoro et al. (2020) observed that inmates of a custodian centre in Enugu state, Nigeria that attained higher level of education were more knowledgeable about COVID-19 than other inmates. The positive correlation between the scores of COVID-19 knowledge and education level of the respondents perhaps reflects their source of information on the disease and how they understood the information. In our study, the respondents with the highest average knowledge score, i.e., master's and above, received COVID-19 related information from diverse channels/sources (an average of 5.1 sources/individual) (Table 5). This finding could mean that their chances of encountering information on the questions asked in the questionnaire are also higher. It may not be feasible to increase the number of channels/sources of information for the respondents with junior secondary school education or loweras a strategy to improve their understanding of the disease. Rather, more information on COVID-19 may be incorporated into the major channels these individuals receive information. These channels are, FM radio stations and local TV stations (Table 5).

Positive attitude towards the final successful control of COVID-19 is high in this study. This optimistic attitude is ubiquitous globally, as shown in studies with Ethiopian(Aynalem et al., 2020), Tanzanian (Rugarabamu et al., 2020), Chinese (Zhong et al., 2020) and Malay (Azlan et al., 2020) populations as well as a multinational study with respondents from six continents (Ali et al., 2020). Thus, a positive attitude on final success is likely unrelated to any demographic characteristic. In studies that used the same questions on attitude with our study, 84\% Ethiopian and Paraguayans, 96\% Malays and $97 \%$ Chinese respondents have confidence that their country will win the battle against COVID-19. In our sample, the rate was $71 \%$. The researchers from China and Malaysia attributed the high level of confidence on the government to the drastic efforts taken by the authorities during previous and current pandemics (Azlan et al., 2020; Zhong et al., 2020). It remains to be investigated whether the individuals in our sample perceived the government'sCOVID-19 control efforts negatively, which led to the overall lower confidence in the government. Significantly, we found that bad COVID-19 practices in terms of wearing of face mask and washing of hand were higher in the respondents with a negative attitude towards the government (Supplementary Table 2). Thus, it is critical to address the factors associated with negative attitudes towards the government as this may undermine the fight against COVID-19. Although the respondents with a negative attitude towards the Nigerian government's ability to control COVID-19 had a lower average knowledge score than those who had confidence (Supplementary Table 3), we do not know whether there is a causal relationship. Thus, we cannot at this stage recommend improving COVID-19 knowledge as a measure to increase confidence in government or vice versa.

Effective COVID-19 control measures rely heavily on good COVID-19 related practices. Social distancing has been recognised as a very important of such practices (Lewnard and Lo, 2020). In this study, men were more likely to have attended a crowded place in the last two 
weeks, a time when lockdown order was in effect.

The majority of these men were above 40 years of age and worked as civil servants or physical labour/self-employed/local business owners. Although we did not ask the respondents on the nature of the crowded place they have attended, these crowds may be unrelated to workplaces, since most businesses were closed and civil servants below level 12 were ordered to work from home. This finding could indicate that older adults were attending social, religious or other forms of gatherings during the lockdown. Thus, considering that this age group is more vulnerable to the fatal effects of COVID-19 (Onder et al., 2020), they should be targeted for enlightenment on proper social and physical distancing etiquettes. The outcome is particularly important for our respondents belonging to the physical labour/self-employed/local business employment group who also have the least frequency of face mask use and frequent hand washing compared to all employment groups (Table 2).

Since the early stages of the pandemic, a great scourge of conspiracy theories appeared online, leading to misinformation and disinformation on the virus (Van Bavel et al., 2020). Misconceptions about the disease may undermine efforts for immediate as well as long-term control measures, especially vaccines (Jolley and Douglas, 2014). In an earlier crosssectional survey of internet users, $47 \%$ of Nigerians held the misconception that COVID-19 was a biological weapon (Olapegba et al., 2020). A larger proportion of our study respondents (83\%) held at least one misconception on COVID-19. Respondents with a lower level of education had the highest rates of misconception, negative attitudes and bad COVID-19 related practices, the lowest source of COVID-19 related information and appear to trust any source they receive COVID-19 related information from. It is therefore important for local stations to include campaigns that debunk misinformation and disinformation about the disease. This finding is very critical for the future of Nigeria's fight against COVID-19, considering the previous scepticisms of the North-West Nigeria region regarding vaccines, incidentally, also triggered by similar misconceptions (Ghinai et al., 2013).

CONCLUSION

To the best of our knowledge, this is the first study to investigate the KAP and misconceptions towards COVID-19 focused on the Hausa ethnic group. The findings of this study suggest that the study respondents had good knowledge of COVID-19. The effect of the level of education of the respondents on their COVID-19 related practices and the misconceptions they held calls for more research on the general public, which inevitably has a higher proportion of less educated individuals than our sample. We have also identified the main channels the respondents receive COVID-19 related information and the sources they are likely to trust the most, which could be used to deliver targeted information.

\section{Recommendation}

- It is recommended that other community engagement strategies, beyond social mobilisation should be incorporated in the control measures against COVID-19.

- Factors that need to be considered when communicating and imposing policies should include the current security situations, economic conditions, norms, values and past experience of the communities.

- Consultations channels aimed at getting feedback from the people, partnership with members of the community and ensuring culturally and religiously appropriate messages may improve cooperation by the people.

- Measures that will increase health seeking behaviour and contact with healthcare units and health care workers on matters associated with COVID-19 are encouraged, considering that majority of the respondents placed trust on them for information.

- Preferably, the healthcare workers should be encouraged to practice in their own communities or places where they are considered as peers.

- Finally, there is the need for the government and relevant stakeholders to strategize on how best to tackle COVID-19 related misconceptions in the North-Western region before the inevitable arrival of vaccines.

\section{Limitations and strengths}

One major limitation for our study is sampling bias. Our study sample composed of respondents reached via WhatsApp, and thus, non-users of the internet, which form the majority of the population, are not part of the study population. The strength of the study is the large sample size. Therefore, the strong association between level of education and many dependent variables in the study could be 
used to set research questions for future studies. Furthermore, it is reasonable to design campaigns and policies targeting internet users (about 2.4 million (National Bureau of Statistics, 2019)), who mainly reside in the more urbanised areas of the state where COVID-19 is spread.

\section{Data availability}

The data that supports the findings of this survey and the supplementary materials are available from the corresponding author and may be provided upon reasonable request.

Conflicts of interest

The authors declare no conflict of interest

Source of funding

This research did not receive any funding

Author contribution

Murtala Bindawa Isah: Conceptualization, Development of questionnaire, Data collection, Statistical Data analysis, Result Interpretation, Manuscript Writing - original draft, Manuscript Writing - review \& editing.

Mahmud Abdulsalam: Conceptualization, Development of questionnaire, Data collection, Manuscript Writing - review \& editing.

Abubakar Bello: Conceptualization, Development of questionnaire, Data collection, Manuscript Writing - review \& editing.

Muawiyya Idris Ibrahim: Data collection, Statistical Data analysis, Result Interpretation, Manuscript Writing - review \& editing.

\section{REFERENCES}

Ali, M., Uddin, Z., Banik, P. C., Hegazy, F. A., Zaman, S., Ambia, A. S. M., . . . Bahalul, S. M. (2020). Knowledge, attitude, practice and fear of COVID-19: A crosscultural study. medRxiv. doi:DOI: 10.1101/2020.05.26.20113233

Alqahtani, A. S., Rashid, H., Basyouni, M. H., Alhawassi, T. M., \& BinDhim, N. F. (2017). Public response to MERS-CoV in the Middle East: iPhone survey in six countries. Journal of Infection and Public Health, 10(5), 534-540.

Arons, M. M., Hatfield, K. M., Reddy, S. C., Kimball, A., James, A., Jacobs, J. R., . . . Oakley, L. P. (2020). Presymptomatic SARS-CoV-2 infections and transmission in a skilled nursing facility. New England Journal of Medicine, 382, 2081-2090.

Aynalem, Y. A., Akalu, T. Y., Gebresellassie, B., Sharew, N. T., \& Shiferaw, W. S. (2020). Assessment of undergraduate student knowledge, practices, and attitude towards COVID-19 in Debre Berhan University, Ethiopia. Research Square. doi:DOI: 10.21203/rs.3.rs28556/v1
Aminu Usman: Conceptualization, Development of questionnaire, Data collection, Manuscript Writing - review \& editing.

Abdullahi Nasir: Data collection, Manuscript Writing - review \& editing.

Bashir Abdulkadir: Conceptualization, Development of questionnaire, Data collection, Manuscript Writing - review \& editing.

Ahmed Rufa'i: Data collection, Manuscript Writing - review \& editing.

Kabir Matazu Ibrahim: Data collection, Manuscript Writing - review \& editing.

Aminu Sani: Conceptualization, Development of questionnaire, Development of online questionnaire, Data collection, Manuscript Writing - review \& editing.

Ma'awuya Aliu: Data collection, Manuscript Writing - review \& editing.

Shema'u Abba Kabir: Development of questionnaire, Data collection, Manuscript Writing - review \& editing.

Abdullahi Shuaibu: Development of questionnaire, Data collection, Manuscript Writing - review \& editing.

Shafique Sani Nass: Conceptualization, Development of questionnaire, Manuscript Writing - review \& editing.

Acknowledgement

The authors acknowledge the effort of the individuals that participated in data collection.

Azlan, A. A., Hamzah, M. R., Sern, T. J., Ayub, S. H., \& Mohamad, E. (2020). Public knowledge, attitudes and practices towards COVID-19: A cross-sectional study in Malaysia. Plos One, 15(5), e0233668.

Bai, Y., Yao, L., Wei, T., Tian, F., Jin, D.-Y., Chen, L., \& Wang, M. (2020). Presumed Asymptomatic carrier transmission of COVID-19. JAMA, 323(14), 1406-1407.

Dorcas, S., Emmanuel, L., Anthony Baffour, A., Ephraim Kumi, S., \& Jude Kyeremeh, A. (2020). Knowledge, risk perception and preparedness towards coronavirus disease-2019 (COVID-19) outbreak among Ghanaians: a quick online cross-sectional survey. Pan African Medical Journal, 35(2), 44. doi:DOl: 10.11604/pamj.supp.2020.35.2.22630

Ferguson, N., Laydon, D., Nedjati Gilani, G., Imai, N., Ainslie, K., Baguelin, M., . . . Cuomo-Dannenburg, G. (2020). Report 9: Impact of non-pharmaceutical interventions (NPIs) to reduce COVID19 mortality and healthcare demand. Imperial College London. doi:DOI: https: / / doi.org/10.25561/77482 
Gandhi, M., Yokoe, D. S., \& Havlir, D. V. (2020). Asymptomatic transmission, the Achilles' heel of current strategies to control COVID-19. New England journal of medicine, 382, 2158-2160.

Geldsetzer, P. (2020). Knowledge and perceptions of COVID-19 among the general public in the United States and the United Kingdom: A cross-sectional online survey. Annals of internal medicine. doi:DOI: 10.7326/M20-0912

Ghinai, I., Willott, C., Dadari, I., \& Larson, H. J. (2013). Listening to the rumours: What the northern Nigeria polio vaccine boycott can tell us ten years on. Glob Public Health, 8(10), 1138-1150.

Gidado, S., Awosanya, E., Haladu, S., Ayanleke, H. B., Idris, S., Mamuda, I., . . . Nguku, P. (2018). Cholera outbreak in a naïve rural community in Northern Nigeria: the importance of hand washing with soap, September 2010. Pan African Medical Journal, 30(5).

Hutin, Y., Luby, S., \& Paquet, C. (2003). A large cholera outbreak in Kano City, Nigeria: the importance of hand washing with soap and the danger of streetvended water. Journal of Water Health, $1(1), 45-52$.

Iliyasu, G., Ogoina, D., Otu, A. A., Dayyab, F. M., Ebenso, B., Otokpa, D., . . . Habib, A. G. (2015). A multi-site knowledge attitude and practice survey of Ebola virus disease in Nigeria. PloS One, 10(8).

Jolley, D., \& Douglas, K. M. (2014). The effects of anti-vaccine conspiracy theories on vaccination intentions. PloS One, 9(2).

Lewnard, J. A., \& Lo, N. C. (2020). Scientific and ethical basis for social-distancing interventions against COVID-19. Lancet Infectious Diseases, 20(6), 631-633. doi:DOI: $10.1016 /$ S1473-3099(20)30190-0

National Bureau of Statistics. (2018). 2017 Demographic statistics bulletin Retrieved from PDF: http: / / nigerianstat.gov.ng/download/77 5

NCDC. (2020a). COVID-19 Nigeria. Retrieved from https: / / covid19.ncdc.gov.ng/

NCDC. (2020b). First case of corona virus disease confirmed in Nigeria. Retrieved from

https: / /ncdc.gov.ng/news/227/firstcase-of-corona-virus-disease-confirmedin-nigeria

Okoro, J., Odionye, T., Nweze, B., Onuoha, M., Ezeonwuka, C., Owoh, J., \& Nkire, J. (2020). COVID-19 pandemic, psychological response to quarantine, and knowledge of the disease among inmates in a Nigerian custodial center [version 1; peer review: 1 approved with reservations]. Emerald Open Research, 2(26), 26.

Olapegba, P. O., Ayandele, O., Kolawole, S. O., Oguntayo, R., Gandi, J. C., Dangiwa, A. L., . . . lorfa, S. K. (2020). A Preliminary Assessment of Novel Coronavirus (COVID19) Knowledge and Perceptions in Nigeria. MedRxiv. doi:DOI: 10.1101/2020.04.11.20061408

Onder, G., Rezza, G., \& Brusaferro, S. (2020). Case-fatality rate and characteristics of patients dying in relation to COVID-19 in Italy. JAMA, 323(18), 1775-1776.

Rugarabamu, S., Ibrahim, M., \& Byanaku, A. (2020). Knowledge, attitudes, and practices (KAP) towards COVID-19: A quick online cross-sectional survey among Tanzanian residents. MedRxiv. doi:DOI: 10.1101/2020.04.26.20080820

UNICEF. (2017). Promising practices in WASH. Retrieved from PDF: https://www.unicef.org/nigeria/media/1 476/file/Nigeria-promising-practices-inWASH.pdf.pdf

UNICEF. (2020). NIGERIA Final Evaluation of the Water, Sanitation and Hygiene Program 2014-2017 between the Federal Government of Nigeria \& UNICEF. Retrieved from PDF https: / / www.unicef.org/evaldatabase/fil es/MASTER_Final1_Evaluation_Report_W ASH_Program_2014-

2017_Nigeria_14Feb2020.pdf

Van Bavel, J. J., Baicker, K., Boggio, P. S., Capraro, V., Cichocka, A., Cikara, M., . . - Druckman, J. N. (2020). Using social and behavioural science to support COVID-19 pandemic response. Nature Human Behavior, 4, 460-471.

Wakabi, W. (2008). New Nigerian CDC to tackle infectious diseases. Lancet Infectious Diseases, 8(3), 154.

WHO. (2020a). Coronavirus. Retrieved from https: / /www. who.int/healthtopics/coronavirus\#tab=tab_2

WHO. (2020b). Coronavirus disease 2019 (COVID-19): situation report, 73. Retrieved from https://www.who.int/emergencies/disea ses/novel-coronavirus-2019/situationreports

WHO. (2020c). Coronavirus disease (COVID-19) advice for the public: Myth busters. Retrieved from https://www.who.int/emergencies/disea 
ses/novel-coronavirus-2019/advice-forpublic/myth-busters

WHO. (2020d). Covid-19 situation update for the WHO african region, 27 May 2020. Retrieved

from

https: / /apps.who.int/iris/bitstream/han dle/10665/332199/SITREP_COVID19_WHOAFRO_20200527-eng.pdf

WHO. (2020e). Modes of transmission of virus causing COVID-19: implications for IPC precaution recommendations. Retrieved from https://www.who.int/publicationsdetail/modes-of-transmission-of-viruscausing-covid-19-implications-for-ipcprecaution-recommendations

WHO. (2020f). New WHO estimates: Up to 190 000 people could die of COVID-19 in Africa if not controlled. Retrieved from https: / /www.afro.who.int/news/newwho-estimates-190-000-people-could-diecovid-19-africa-if-not-controlled

WHO. (2020g). Risk Communication and Community Engagement (RCCE) Action Plan Guidance COVID-19 Preparedness and Response Retrieved from https://www. who.int/publicationsdetail/risk-communication-andcommunity-engagement-(rcce)-actionplan-guidance

WHO. (2020h). Statement on the meeting of the International Health Regulations (2005) Emergency Committee regarding the outbreak of novel coronavirus (2019nCoV). Retrieved from https: / /www. who.int/newsroom/detail/23-01-2020-statement-on- the-meeting-of-the-international-healthregulations-(2005)-emergencycommittee-regarding-the-outbreak-ofnovel-coronavirus-(2019-ncov)

Wilder-Smith, A., Chiew, C. J., \& Lee, V. J. (2020). Can we contain the COVID-19 outbreak with the same measures as for SARS? Lancet Infect Dis, 20(5), E102E107.

Worldometer. (2020). Coronavirus update. Retrieved from https: / / www.worldometers.info/coronav irus/

Yu, X., \& Yang, R. (2020). COVID-19 transmission through asymptomatic carriers is a challenge to containment. Influenza Other Respir Viruses, 14(4), 474-475.

Zhao, S., Lin, Q., Ran, J., Musa, S. S., Yang, G., Wang, W., . . . He, D. (2020). Preliminary estimation of the basic reproduction number of novel coronavirus (2019-nCoV) in China, from 2019 to 2020: A datadriven analysis in the early phase of the outbreak. International Journal of Infectious Diseases, 92, 214-217.

Zhong, B.-L., Luo, W., Li, H.-M., Zhang, Q.-Q., Liu, X.-G., Li, W.-T., \& Li, Y. (2020). Knowledge, attitudes, and practices towards COVID-19 among Chinese residents during the rapid rise period of the COVID-19 outbreak: a quick online cross-sectional survey. International Journal Biological Sciences, 16(10), 17451752. 